\title{
Moral and Political Prudence in Kant
}

\author{
Eric Sean Nelson
}

\begin{abstract}
This paper challenges the standard view that Kant ignored the role of prudence in moral life by arguing that there are two notions of prudence at work in his moral and political thought. First, prudence is ordinarily understood as a technical imperative of skill that consists in reasoning about the means to achieve a particular conditional end. Second, prudence functions as a secondary form of practical thought that plays a significant role in the development of applied moral and political judgment. The political judgment of citizens and politicians is prudence regulatively guided by right and virtue. As informed by regulative ideas, prudential judgment negotiates the demands of these ideas in relation to the cultural, political, and social realities of a particular form of life. This sense of prudence is empirically informed and involves a context-sensitive application of morality as well as conceptions of individual and general welfare.
\end{abstract}

\section{KANT, MORALITY, AND THE ART OF POLITICAL PRUDENCE}

$\mathrm{K}$ ANT IS WELL-KNOWN for denying the moral significance of prudence (Klugheit). ${ }^{2}$ Prudence cannot justify the moral point of view or morally motivate an agent. In this sense prudence signifies either (1) the deliberation about means for arbitrarily given ends, or (2) the conditional determination of the inherently indeterminate concept of happiness as an end and the means to achieve it. ${ }^{3}$

${ }^{1}$ All references to Kant's works will be to the Akademie edition, cited by volume and page, unless otherwise noted: Immanuel Kant, Kants Gesammelte Schriften, Königliche Prüssische Akademie der Wissenschaften (Berlin: Walter de Gruyter, 1902-1997). A much shorter and substantially different version of this paper appeared as "Kant and the Art of Political Prudence" in Kant und die Berliner Aufklärung, Vol. 4, ed. V. Gerhardt, R. Horstmann, and R. Schumacher (Berlin: Walter de Gruyter, 2001), pp. 220-27.

${ }^{2}$ The denial of the strictly moral import of prudence is often taken to be a denial of prudence as such. Ronald Beiner, for example, accuses Kant of "a thoroughgoing renunciation of ancient practical philosophy," in particular its idea of appropriate judgment, and he criticizes Kant for lacking an adequate account of prudence understood as phronesis in his Political Judgment (Chicago: Univ. of Chicago Press, 1983), pp. 63-71.

${ }^{3}$ Kant claimed that "Prudence is directed only to means . . . and [is] no part of ethics" in the Opus Postumum, trans. Förster and Rosen (Cambridge: Cambridge Univ. Press, 1993) 22: 39. These are technical imperatives of skill in the Grounding of the Metaphysics of Morals, where prudence or pragmatic imperatives concern the identifiable but indeterminate end of happiness or self-interest. See Immanuel Kant, Grounding of the Metaphysics of Morals, third edition, trans. J. Ellington (Indianapolis: Hackett, 1993), pp. 416-20. In his Lectures on Ethics prudence has a complementary role to morality but also has more significant characteristics than in his later writings. See Immanuel Kant, Lectures on Ethics, trans. L. Infield (New York: Harper and Row, 1963), pp. 4-5. 
Because of this hypothetical and conditional character, Kant argued that prudence is not a moral category.

Prudence might be political, but it is not just. The German word Klugheit even intimates an amoral or immoral cleverness, and Kant often equated it with the strategic guile and dishonesty of politicians. Prudence does not seem to have much of a role in Kant's practical philosophy and, accordingly, has not been given much significance in its interpretation. Kant's political thought is either interpreted as determined by the a priori concepts of the doctrine of right (thus assimilating it to morality) or taken to call for an unwritten "critique of political judgment" based on the notion of reflective judgment. Both views agree in disregarding the import of empirically contingent conditions and prudence for political judgment. ${ }^{4} \mathrm{Kim}-$ berly Hutchings, for example, concludes that "political judgment is a species of reflective judgment and can only be genuinely exercised when uncontaminated by empirical interest." 5

Hutchings's claim is correct insofar as Kant considered the dangers of taking a prudential rather than the moral point of view on governance in Perpetual Peace. Prudence, concerned with success and inextricably entangled with empirical interests, would seem to undermine the relevance of moral claims applied to politics. Kant therefore concluded that prudence in this sense undermines morality: "If, however, enlightened concepts of political prudence lead us to believe that the true honor of a nation lies in its continual increase of power by whatever means necessary, this judgment [of the moral requirement of peace] will appear academic and pedantic" (8: 344). Political prudence is consequently, at first sight, only the politician's selfinterested strategic attitude that denies the relevance and truth of the moral point of view in his or her concern for acquiring power.

Kant's practical philosophy is often contrasted with contextual, hermeneutical, and prudential articulations of moral life. Prudential critics of Kant have argued that his practical philosophy ignores the context-specificity of moral judgment with disastrous results. ${ }^{6}$ Accordingly, it is suggested, Aristotle's notion of phronesis is misrepresented in Kant's criticism of instrumental rationality as serving self-interest (prudence). Because of its emphasis on the formal and universal aspects of the moral point of view, Kant's ethics is seen as lacking Aristotelian phronesis, Confucian propriety, or hermeneutical tact, that is, the ability to act morally according to the specific demands of a given context. In this criticism prudence is not taken to be Kant's hypothetical imperative of instrumental reasoning furthering self-interest.

\footnotetext{
${ }^{4}$ Roger Sullivan places politics under morality but notes: "Kant, however, is not naive about political realities, and he also maintains that morality does not require us to be foolish in dealing with inconsistencies between the moral and civil law." Roger Sullivan, Immanuel Kant's Moral Theory (Cambridge: Cambridge Univ. Press, 1989), p. 251. This leaves open the question of the import of being prudent in the sense of not being foolish in Kant's conception of practical life.

${ }^{5}$ Kimberly Hutchings, Kant, Critique and Politics (London: Routledge, 1996), p. 53.

${ }^{6}$ For example, R. Beiner identifies Kant's political thought with the determinate and universal concepts of right and the teleology of nature through which providence is assumed to promote progress (Beiner, 1983, pp. 63-71).
} 
Prudence is a "sense of appropriateness" - a phrase that signifies an ability to consider the contextual character of a particular moral situation. ${ }^{7}$

Prudence has at least two meanings in this debate: (1) instrumental rationality in the service of self-interest — and this is Kant's primary usage of the term, ${ }^{8}$ — and (2) context-sensitive judgment that considers the proverbial right means at the right time in the right place. It is undeniable that Kant mostly used Klugheit in the first sense. I will argue, however, that the second sense does in fact play an important role in what Robert Louden has called Kant's "impure ethics." In this paper, this expression refers to the empirically influenced realm of deliberation and evaluation found in Kant's writings on education, history, and politics. Kant explicitly argued that the political judgment of citizens and politicians necessarily and rightly incorporates prudence. It must do so if only for the reason that both the interest in general and individual welfare, which is necessary for finite and natural rational beings to survive and flourish, and the concern for appropriate application of moral judgment call for it.

If politics is to be understood morally, it needs to be seen from the perspective of not only the moral law as such but the doctrines of right and virtue developed in the Metaphysics of Morals. ${ }^{9}$ But political judgment does not follow from the doctrines of right and virtue as determinate judgments that subsume particulars under a universal rule. The prudential application of right and virtue is needed in regard to situated institutions and practices. These institutions and practices share in a level of development of a culture and nation that needs to be taken into consideration in political judgment. Because prudence can only be regulatively guided by the categories of right, prudential judgment employs these ideas indirectly. That is, the universal demands of morality and the conditional character of the empirical situation are adjusted and coordinated in prudence insofar as prudence is not constituted by the demands of morality. Regulative ideas of right, such as the ideal constitutional republic, do not disregard prudential application but rather demand it.

Politics is, therefore, only indirectly determined by the categories of right. Kant expressed this difference in his distinction between art and those domains that are capable of a canon, doctrine, or science. Politics, according to Kant, is an art rather than a science or doctrine. ${ }^{10}$ Kant described politics as the art of using the mechanism of nature in order to govern men in Perpetual Peace (8: 372). ${ }^{11}$ In another

\footnotetext{
${ }^{7}$ See Klaus Günther's discussion of the question of phronetic judgment in Kant in The Sense of Appropriateness, trans. J. Farrell (Albany: SUNY Press, 1993), pp. 5-7, 171. Günther attempts to show the more nuanced character of deontological moral judgment and application in response to criticisms.

${ }^{8}$ For an account of the type of hypothetical imperatives called pragmatic or prudential, see Sullivan, 1989, pp. 31-36.

${ }^{9}$ Immanuel Kant, Metaphysics of Morals, trans. M. Gregor (Cambridge: Cambridge Univ. Press, 1991).

${ }^{10}$ Because of the a posteriori and empirical character of the art of prudence, Kant claimed that no canon can be provided for it (A 800/B 828). On the difference between doctrine or science and art, compare my discussion of this issue in "Schleiermacher on Language, Religious Feeling, and the Ineffable," Epoché: A Journal for the History of Philosophy 8:2 (2004) 297-312.

${ }^{11}$ The following translation is used in this paper: Immanuel Kant, Perpetual Peace and Other Essays, trans. T. Humphrey (Indianapolis: Hackett, 1983).
} 
work, Kant called government and education the "two most difficult arts" (9: 446). Since politics is limited and conditioned by right and virtue (morality), it does not directly follow or derive from the concepts and doctrines of morality (8: 372). The political has a relative independence from morality. It is limited and oriented by right and virtue through duty, but its materiality and empirical content means that it is not constituted and defined by them.

Political judgment is not a form of determinate judgment for Kant. Nor is it a form of reflective judgment, since—as prudential judgment—politics is an art involving empirical variety and conceptual indeterminacy. It is an art that adjusts empirical and universal considerations, an art in which the universal (the demands of morality) determines the empirical particulars indirectly as regulative ideas. Political judgment in this case requires a "sense of appropriateness," of appropriate judgment, prudence, or practical intelligence (Klugheit). Politics does not simply apply right to society as if the latter could be subsumed under or be determinate concepts of the doctrine of right. Since politics is empirical, it is by definition not a concept determined $a$ priori. Political judgment consequently requires an adjudication and negotiation in which the political is limited and oriented according to right.

Political prudence concerns the consideration of ideal right, including the fundamental idea of right of a republican constitution, in relation to the historical context of institutions and practices. This context calls forth the examination of the realities of society. Political prudence is a necessary feature of the health and welfare of society. It is an art of becoming a citizen in civil society and an art of governance that can be oriented toward the possibility of reforming institutions according to justice.

Although Kant's practical philosophy does not seem to offer the possibility of reconciling transcendental-normative and contextual interpretations of the ethical, of pure a priori and impure empirical ethics, ${ }^{12}$ his political philosophy suggests that a coordination of moral and prudential judgment is possible and necessary for citizenship and governance. Kant's political writings articulate this possibility insofar as politics does not exclusively fall under the concept of right and, as the application of the concept of right, politics is regulatively oriented toward right without being solely subordinated to it.

\section{RECONSIDERING KANT'S NOTION OF PRUDENCE}

Kant rejected the idea that prudence can be a justification for morality. The imperative of morality is categorical rather than hypothetical. His criticisms of prudence are aimed at those theories that seek to ground morality in conditional reasoning about happiness and other empirically diverse and teleologically structured goals (4: 417-19). Kant denied prudence a fundamental role in ethics since it is insufficient to establish the autonomy, impartiality, and universality of the moral law.

Kant did not deny the significance that technical imperatives of skill and pragmatic imperatives of prudence have for deliberation and evaluation in common

\footnotetext{
${ }^{12}$ Robert Louden develops a thorough critique of this view in Kant's Impure Ethics: From Rational Beings to Human Beings (Oxford: Oxford Univ. Press, 1999).
} 
life. ${ }^{13}$ Although they are not moral in a categorical and unconditional sense, they are necessary to the practical reasoning of finite rational creatures with a sensuous nature. In Grounding of the Metaphysics of Morals, prudence is described as the art of treating others with a view toward the maximization of one's own personal happiness. The conditional hypothetical imperatives of prudence address one as counsels instead of as moral requirements. They are, therefore, advice to undertake $x$ in order to realize the possible happiness of $y$ and they can be freely followed or not as a matter of choice without being evaluated as morally wrong or right (4: 416).

I want to suggest that prudence in Kant does not only consist of the art of maximizing personal welfare and one's own individual goods. Prudence is also the art of promoting the general or public welfare. Although Kant excluded any principle such as utility from morality, he did not exclude considerations of happiness and welfare from politics. Kant thus justified a whole domain of law and policy, namely, pragmatic laws and sanctions, as being determined by the empirical need to provide for the general welfare (4: 419f).

Kant's practical thought needs to be re-evaluated in light of these "impure" considerations. That this can be consistently ascribed to Kant can be shown by Kant's use of notions and arguments developed in the First and Third Critiques. Kant argued, for example, that the happiness aimed at by prudence, whether general or individual, is not an ideal of reason but of the imagination. Ideals of the imagination play a role in a number of places throughout Kant's corpus, and it is an ideal that he described as resting on empirical grounds (4: 419).

Pragmatic imperatives require reasoning about empirical conditions. Since it appeals to ideals of the imagination and symbols, prudence does not have the determining capacity that reason does. Yet it is nevertheless necessary, if not sufficient, for both the individual and the state, given the empirical conditions and interests of civil society. For Kant, neither the individual nor society would function without the pragmatic consideration of the ends of welfare and the various means of promoting these ends.

Kant's account of education gives this argument further validity. In his Lectures on Education, Kant emphasized the importance of non-moral forms of practical imperatives for the education of the child into society (socialization). Kant distinguished three types of education (Bildung) in this work. The first is called the "scholasticmechanical." It is the teaching of skill and is essentially didactic. The second is "pragmatic" education. It involves the cultivation of prudence. Finally, moral education cultivates the ethical (9: 445). All three are considered practical, rather than theoretical, but only the third is moral in the strict sense. ${ }^{14}$ Kant considered these

\footnotetext{
${ }^{13}$ However, at times Kant suggested that pragmatic imperatives of prudence and technical imperatives of skill are both merely corollaries of theoretical reason (5:172). But in his ethical writings he emphasizes the conditional ought-character of pragmatic imperatives. Thus, in the Lectures on Ethics, "Practical philosophy contains no technical rules: it contains only rules of prudence and morality, and it is, therefore, pragmatic and ethical" (Kant, 1963, p. 4). In the Grounding, all imperatives express an "ought." Hypothetical imperatives of skill and prudence are thus practical in expressing a conditional "ought." Technical imperatives are even here corollaries in that they are derived from theoretical information about what is (4: 413, 415-6).

${ }^{14}$ Kant sometimes considered only the moral as such to be practical (5:172), sometimes only the moral and prudential (Kant, 1963, p. 4), and sometimes all three.
} 
three stages, and they are repeated in other works, ${ }^{15}$ to represent the development of the moral "psychology" of the individual.

In these lectures scholastic education aims at the ability or skill of achieving ends, whereas pragmatic education is given a middle role between the instrumental realization of ends and the categorical demands of morality (9: 445). In this text prudence is understood differently than in his central moral writings. It is not simply the calculation of means according to indefinite ideas of happiness. Prudence is clarified according to the concepts of citizenship and civil society, which is a realm of realizing happiness. ${ }^{16}$ The ordinary view of Kant fails to make sense of this side of Kant's thought and statements such as: "A person is cultivated into a citizen through the education of prudence, through [prudence] he receives a public value" (9: 445). The education of prudence is a cultivation of the ability to be a member of civil society. Educating prudence means becoming a citizen capable of participating in the life and decisions of that society. Kant continues this statement with the assertion that what the youth learns in learning prudence is (1) to direct civil society according to his intentions and (2) to direct his intentions according to civil society (9: 445). Elsewhere prudence is the capacity to direct other rational beings according to one's own intentions, ${ }^{17}$ but here — as in some of the political writings-prudence requires the coordination of my own and others' interests.

Prudence does not only concern the calculation of individual and general welfare. In addition, prudence in the citizen is an art of negotiation between one's own and others' interests. On the one hand, it is "knowledge of the art of how one human being can exercise influence on another and lead him according to his intention" and, on the other, the pragmatic is that which "makes us prudent and useful in public matters, where we necessarily have not merely theory but also practice." 18 Prudence is, therefore, a cultivated ability to participate with others in public life with a view towards the interests of others and the general welfare. As such, prudence is not an accidental aspect of social life. It is secondary to morality for Kant and yet essential to practical reasoning and interaction in society.

According to Kant, the person only receives universal value or worth (as human) through morality. In and through the cultivation of prudence, however, the person becomes a citizen of a determinate social order and connects his own goals and needs with those of society in general. Because prudence already creates a social bond and the reciprocity of interests between agents, Kant could appeal in Perpetual Peace to a prudential constitution established among a group of rationally self-interested devils. A nation of devils, if they were prudent, could create a relatively well-ordered

\footnotetext{
${ }^{15}$ Such as Reflexion 1482, 15: 689.

${ }^{16}$ Civil society, briefly described, is a configuration of those aspects of society that rest outside the state. It exists "between" the individual and the state. In this sense it consists of the organization of a "private realm" of individuals in pursuit of their own economic interests as well as those of extra-governmental associations and publics.

${ }^{17}$ 20: 200; Immanuel Kant, Lectures on Philosophical Theology, trans. Wood and Clark (Ithaca: Cornell Univ. Press, 1978) p. 92.

${ }^{18}$ From Immanuel Kants Menschenkunde oder philosophische Anthropologie, ed. Starke (XV, I: 5). Cited in and translated by Louden, 1999.
} 
society. Such a society would not presuppose moral improvement but would employ the art of applying "the mechanism of nature to men"; the establishment of such a prudential but well-ordered constitution would in turn promote morality (8: 366). This argument makes no sense from a purely moral interpretation of Kant because it demands the recognition of the constructive role of prudence in his practical philosophy. Kant did not neglect prudence but rethought it as the cultivation of the art of living in society. Prudence mediates between reason and passion, morality and self-interest. It educates and socializes the desires and needs of the individual.

The individual enters into civil society and becomes a citizen through the formation of prudential judgment. Prudence is cultivated through experience and learning from experience, but it is also developed through its relationship with morality proper. Prudence begins with selfishness but is transformed by the guidance of practical reason into a rational self-interest that includes the recognition of others' interests. ${ }^{19}$

What then does it mean for prudence to be the stage of education that civilizes a person and cultivates a citizen and member of civil society? Is it the case that prudence is a necessary feature of practical life that cannot simply be canceled or excluded by the moral point of view? It is these questions, and this sense of prudence, that will concern us in the remaining part of the paper.

\section{THE DOCTRINE OF RIGHT AND ITS PRUDENTIAL APPLICATION}

The justification, including the ultimate norm of the moral point of view in the categorical imperative, and the application of norms should be distinguished as two different practical discourses involving their own respective questions, strategies, and goals. Whereas the Critique of Practical Reason ${ }^{20}$ and the Grounding of the Metaphysics of Morals provide a justification and explication of the moral point of view and a procedure for testing generalized norms (maxims), the Metaphysics of Morals offers an application of Kant's moral theory to the domains of right and virtue. Kant's general moral theory is accordingly differentiated in the Metaphysics of Morals into legality and virtue with their respective orientation to the right and the good. The legitimacy of laws is to be checked according to the categorical structure of right just as the cultivation of virtues refers to the ideal end or good, that virtue is its own reward and establishes the worthiness for happiness (6: 396).

These "applications" of the moral point of view into the discourses of right and virtue continue to be categorical and determinate. The doctrines of right and virtue remain differentiated parts of the a priori and metaphysical level of morality, although at a lesser level of abstraction. This means that they are a priori and related to more empirical content, without which there could be no differentiation, according to the model of determinant judgment that subsumes particulars under

\footnotetext{
19"Pure practical reason must check selfishness, for selfishness, natural and active in us even prior to the moral law, is restricted by the moral law to agreement with the law, when this is done, selfishness is called rational self-love" (5: 73). This does not constitute an elimination of the prudential concern for self-interest, but its transformation through morality such that it is compatible rather than antagonistic with morality.

${ }^{20}$ Immanuel Kant, Critique of Practical Reason, trans. L. W. Beck (New York: Macmillan, 1993).
} 
the universal. This is also why Kant can discuss examples when writing of the categorical imperative. These regional doctrines of morality are more sophisticated in articulating the differentiated and condensed domains of justice and virtue, but they follow from and are included within the moral law. The Metaphysics of Morals is not yet a work of "impure ethics," but (like other "pure" works) it repeatedly enters into such discussions. The doctrines of right and virtue do not need prudence, even if they require the practice of judgment for their own application.

However, the doctrine of right is complicated by the introduction of the "externalities" of social interaction, property relations, and coercion. Already in this work the ideal republic, generated from the principle of right (6: 230), plus some considerations of externality, serves as a model by which to indirectly test the legitimacy of actual constitutions and legal systems. Although the principle of right is categorical, it is elucidated and applied as a regulative idea in the example of the ideal republic that serves to orient the direction that actual governments ought to take. It orients by providing a model of legislation, but it does not give concrete legislation or provide an actual constitution. These depend on circumstance and context. The ideal republic is an ideal of reason when it demands justice and it becomes an ideal of the imagination when it calls for the promotion of general well-being.

Once the principle of right is explicated in the form of an ideal republic, prudence as context-sensitive judgment takes on significance even in the Metaphysics of Morals. The legitimation of government and constitution through the idea of the united will of the people demands in return that the state "make the kind of government suited to the idea of the original contract. Accordingly, even if this cannot be done all at once, it is under obligation to change the kind of government gradually and continually so that it harmonizes in its effect with the only constitution that accords with right, that of a pure constitution" (6: 340).

The doctrine of right in this case is not presenting a strict obligatory right that has to be followed no matter what, since it also allows appeal to the level of social development. Its normative status is not that of a determinate judgment, since its application is not immediately entailed by its concept. In this description of the republican ideal, obligation and application are disjoined insofar as the application of normative right is to be gradually worked for instead of achieved by, for example, immediate and total revolution. Although politics is always to be oriented according to morality (right), political judgment ought to be prudential in adjusting social and political conditions to the ideas of morality. Revolution is not only declared unjust, although elsewhere he justified the French Revolution as signaling the possibility and hope of a morally informed just society, it is described as detrimental to the social condition. The moral demand for justice is thus being restrained by empirical considerations about the order, stability, and welfare of society. The argument developed in this paper, by including prudence as a secondary but significant feature of Kant's practical philosophy, shows that Kant is both consistent on this issue and that it does not fall under Hegel's critique of the "terrorism of the moral law." The prudential concern for reform and welfare implies that the moral law should not be applied in a fanatical and terrorist fashion such that, for instance, the 
French Revolution both hints at the ideal and encourages us to realize it while also remaining inconsistent with it.

The advice about gradually reforming government, instead of directly applying the idea of a republic to reality without prudential mediation, might seem to compromise the rigor of his theory of right. After all, the conformity of the constitution to principles of right is a "condition which reason, by a categorical imperative, makes it obligatory for us to strive after" (6:318). Its realization is unequivocally demanded by right. This refers to the necessity "that it be" realized. But "how" the idea of a constitutional republic is to be instituted is dependent on a sense of appropriate application. Reform rather than violent revolution is justifiable insofar as ideas of right require "prudential application." This contextually responsive application is not intended to undermine the moral force of these norms, but it tempers them against the realities of existing practices and institutions.

There are two significant senses of application that need to be distinguished in Kant's practical philosophy: (1) the application of morally determinate judgment that we find in the principles of right and virtue (i.e., normative deontological application $)^{21}$; and (2) the application of these concepts as a transition from pure and a priori to impure and empirical ethics (i.e., context sensitive or prudential application). The ideal system of right requires application in the first sense; its use in orienting political practice_-including the prodding toward reform as an imperfect obligation - calls for application in the second sense. The second sense of application occurs in two ways: (1) practically as prudential judgment and (2) in a more theoretical way when it involves discussion of the application of moral principles to empirical human nature through definite conceptions of that nature (such as its happiness), a concern that Kant developed in his lectures and notes on anthropology.

Prudence is accordingly the practical form of judgment concerned with the empirical part of ethics that addresses human nature. It is the experience and the learning from experience necessary for relating to the world. It also informs pragmatic forms of empirical inquiry such as history and anthropology. According to Kant, anthropology is moral —in the wider sense of "pragmatic" (that is, prudential)—instead of theoretical because of this practical concern with human nature. The practical import of human nature and its variations is the primary object of this "second part" of, or supplement to, practical philosophy. Kant insisted in his ethical works on the need for both pure and impure ethics, although he devoted most of his attention to the first. Nevertheless, moral philosophy has an empirical part "because it must determine the will of man insofar as the will is affected by nature" (4: 387).

\footnotetext{
${ }^{21}$ This seems to be the primary sense of the passage: "But just as there must be principles in a metaphysics of nature for applying those highest universal principles of a nature in general to objects of experience, a metaphysics of morals cannot dispense with principles of application, and we shall often have to take as our object the particular nature of man, which is known by experience, in order to show in it what can be inferred from universal principles (6: 216-17). The inference from universal principles continues to be a determinate form of moral judgment, their adaptation to empirical and contingent conditions would be prudential application.
} 


\section{PRUDENCE AND REGULATIVE IDEAS OF REASON}

Pure practical reason is constitutive in morality. However, for prudential judgment and for pragmatic fields of inquiry, reason is regulative and orienting. It is regulative because prudential judgment necessarily involves the empirical. In the Critique of Pure Reason Kant claimed that: "By the 'practical' I mean everything that is possible through freedom. When, however, the conditions of the exercise of freewill are empirical, reason can have no other than a regulative employment in regard to it, and can serve only to effect unity in its empirical laws" (A 800/B 828). ${ }^{22}$ Prudence falls under this claim as it is the empirically conditioned exercise of our freedom. It is the possibility of rational freedom being exercised within history and, as such, is potentially oriented (or regulated) by the guiding ideas of reason. Prudence is not necessarily in accord with morality, for example, in the politician who thinks only of power and derides the wisdom of practical reason. Yet prudence can potentially be coordinated with morality in order to fulfill it. Prudence becomes a historical step for morality and can do so even for rationally self-interested devils through such coordination. Prudence serves to bring morality about in that it is informed by it and potentially a transition to it. ${ }^{23}$ Morality cannot be achieved without prudence just as concepts without intuition are empty.

Kant continues the last passage cited from the First Critique by explicitly referring to prudence: "Thus, for instance, in the precepts of prudence, the whole business of reason consists in uniting all the ends which are prescribed to us by our desires in the one single end, happiness, and in coordinating the means for attaining it. In this field, therefore, reason can supply none but pragmatic laws of free action, for the attainment of those ends which are commended to us by the senses; it cannot yield us laws that are pure and determined completely a priori" (A 800/B 828). The "ethics" (practical but not moral in the strict sense) of interests and their coordination is the Kantian pragmatic ethics of prudence unfolded in this paper. In this sense the type of judgment involved in Kant's impure ethics is prudential judgment that determines what happiness is and how to bring it about. It is a lower second tier of the practical that involves conditional and context-dependent judgments oriented and guided by the moral in a regulative rather than a constitutive fashion.

However, Kant did not articulate this ethics of prudence in his moral writings. He presupposed it. He also hints at it. These hints become stronger in his political writings, especially in Perpetual Peace. Perpetual Peace defends morality and makes claims about politics with regard to prudential and manipulative politicians. Instead of dismissing prudence, which he would do if it were irrelevant to common ethical life, Kant argued for a prudence oriented by morality and a morality capable

\footnotetext{
${ }^{22}$ First Critique quotations are from N. K. Smith's translation from Immanuel Kant, Critique of Pure Reason (New York: St. Martin's Press, 1929).

${ }^{23}$ Most interpretations of Kant's philosophy of history concentrate on how providence works through prudence contrary to the intentions of agents. Prudence is a step toward morality, although it does not have moral motivation, in the example of the society of devils. This example also indicates that there is a degree of empirically-contingent "ethics" involved in prudence that could produce a social order that would promote morality simply because it is well-ordered.
} 
of a sense of appropriateness in applying itself to political realities. The interest in reform discussed above is not only a concern for avoiding the violation of right in the name of a greater right. It is a concern for a practice that would effect change with constant regard for the welfare of society. Morality might disregard happiness for moral reasons. For Kant, it is better to do the right thing even if it makes one unhappy. Politics can also be motivated by a sense of sacrifice for justice and virtue. But politics by its very nature (the governing of finite rational creatures) has to include the art of welfare as one of its ends and cannot disregard it.

\section{PRUDENCE AND THE ART OF POLITICS}

Although the direction of reform is determinately set by the principles of right (for we are morally obliged to work toward a constitutional republic), its actual realization cannot be. The moral reform of politics adjusts the given circumstances only gradually and in such a way as not to unleash destructive effects in society. The art of political reform is thus a central part of the art of prudence. This art of appropriate application adjusts given realities according to normative ideas and limits the force and extent of these ideas according to circumstances. Thus, for example, great inequalities of wealth are an injustice defended by government (6: 454). Yet the removal of this injustice is an idea that requires appropriate measures by those that govern insofar as they seek to approximate the idea of justice. Justice is not only a limiting idea of this practice, but this practice limits the direct and immediate idea of justice insofar as it is tied to other institutions and practices. The limiting condition of such demands of right for a just system of government is prudence. ${ }^{24}$ Prudence easily becomes injustice if it ignores the claim of justice made upon it. It must, therefore, heed this call, even in restraining it in its application, if it is to be a morally guided prudence. ${ }^{25}$

If this argument is correct, then Kant's political philosophy is based on morally oriented pragmatic practice. But there is a potentially damaging counter-example. Politics is defined by Kant in Perpetual Peace as applied right and the practical correlate of the "theoretical" doctrine of right. ${ }^{26}$ Kant continues by urging that for there to be a conflict between morality and politics, "one would have to understand morality as a universal doctrine of prudence" (8: 370). This claim that politics is applied right would seem to make the relationship between politics, right, and morality clear; politics is simply to be derived from the concept of right, of which it is the application. This would challenge the argument unfolded in this paper, except that a more complicated relationship ensues in Kant's essay. Kant argued that politics should be subordinate to the concern for morality in such a way that his

\footnotetext{
${ }^{24}$ At times, Kant suggested that it is a lack of skill and experience (and thus prudence) that causes evils such as great inequality: "humanity suffers from the evils that man inflicts upon himself through lack of experience" (8: 118). Of course, experience and the prudential consideration of experience are not the solution on their own, but these under the direction of morality.

${ }^{25}$ This is the essential difference between the moral politician and the political moralist.

${ }^{26}$ For example, when he claimed that "there can be no conflict between politics as an applied doctrine of right and morals as a theoretical doctrine of right" (8: 370).
} 
subsequent arguments presuppose that politics is not identical with or to be absorbed and eliminated into morality. Kant, as we will soon see, explicitly rejects this claim. Kant indicated their compatibility and the possibility of their normative coordination rather than explicating applied right as a determinate and context-insensitive application of pure justice. For Kant, contrary to the standard view, politics ought to occur according to the principles of right, and it ought to involve prudence in applying these principles to the social arena.

As we saw above, Kant rejected prudence as a reason for justifying the moral point of view and as a means for testing the morality of a norm of action. Prudence continued to function as "rational self-interest," as the education of the citizen into a particular civil society, and as sensitivity to the realities of institutions and practices. Kant, therefore, found multiple roles for prudence, especially in politics, even as he made impossible the reduction of morality to prudence. In this sense, insofar as prudence abandons moral reflection and evaluation, Kant's ethics and prudential moral theory are intrinsically incompatible. Yet, the coordination of right and prudence, which Kant argued is necessary for morally informed political practices, should not entail the reduction of politics to morality or morality to politics. The former leads to a dangerous moral rigorism and fanaticism, ${ }^{27}$ the latter leads to the even more harmful elimination of a normative perspective for political life. Without a doctrine of politics, there can be no critique of political reason or political judgment considered as a form of reflective judgment. But politics is not a doctrine or system-it is an art. As an art of practice, politics belongs to Kant's impure and empirically-informed ethics.

Politics can be understood as a prudential realm that ought to be oriented by morality and guided by a reflectively articulated philosophy of history. The alternative interpretations possible here are these: either politics is simply moral and, as the application of morality, requires no coordination or mediation between its principles and political realities, or politics is a realm apart from morality, for it is "positive" in the sense of lacking a further normative basis beyond the legalistic fact of its existence.

The first position-moralized politics-ignores the fact that political order requires the appropriate use of force and coercion, including the internal use of police and the external use of armed forces. Kant's moral critique of war did not exclude the possibility of engaging in war under appropriate conditions. This entails that "in actual experience we can certainly anticipate great deviations from that (theoretical) idea of right" (8: 371). The norms of right do not by themselves fully indicate their employment. For Kant, one has to expect deviations, adjustments, and approximations.

The second position — politicized morality — exercises worldly wisdom without moral wisdom. It is the enlightened calculation of power and would mean that "politics (as the art of using that mechanism [of nature] to govern men) would

\footnotetext{
${ }^{27}$ Kant does not only warn of moral fanaticism in Perpetual Peace. In the Second Critique, it is described as an illegitimate overdetermination of morality that mistakes a symbol for a schema (5: 70), confuses virtue and holiness (5: 84), and reifies the supersensible through intuition and feeling (5: 136).
} 
be the whole of practical wisdom and the concept of right would be a contentless thought" (8: 372). In this case there would only be prudence: "a practice that is based on empirical principles of human nature and that does not regard it demeaning to formulate its maxims in accord with the way of the world can alone hope to find a secure foundation for its structure in political prudence" (8: 371). But pure prudence is a very indefinite and insecure structure. Without the orientation of the moral point of view, prudence becomes the calculation of self-interest and power. It is morally indifferent in its contextual disregard for consistency and its "appropriateness" becomes arbitrary and manipulative.

Kant developed an alternative third position that would avoid both the dogmatic moralization of politics and the cynical politicization of morality. The third option is precisely the coordination of the moral (right) and the political (prudence). Kant's essay on peace is the attempt to articulate and defend the possibility of a morally informed prudential politics that listens to the voice of conscience and justice. He therefore suggests: "if we find it absolutely necessary to couple politics with the concept of right, and even to make the latter a limiting condition of politics, the compatibility of the two must be conceded" (8:372). This coupling is articulated in the example of the moral politician whose practice is oriented to instantiating ideas of right through the coordination of maxims of justice and maxims of expediency. Kant asserted both the possibility and coherence of this third option of the moral politician in the following way: "I can actually think of a moral politician, i.e., one who so interprets the principles of political prudence that they can be coherent with morality, but I cannot think of a political moralist, i.e., one who forges a morality to suit the statesman's advantage" (8: 372).

The moral politician makes it a duty to correct faults according to ideas of right. However, his practice is also guided by prudence. Kant argued, for example: "Since it is contrary to all political prudence consistent with morality to sever a bond of political or cosmopolitan union before a better constitution is in place, it would be truly absurd that such a fault be immediately and violently repaired" (8: 372). Kant therefore claimed that, given the prudential supplement to morality, "it is permissible to delay the intention to implement improvements until a better opportunity arises." This means that: "These are permissive laws of reason: to allow a condition of political right afflicted with injustice to continue until everything is either of itself or through peaceful means ripe for a complete transformation, for any legal constitution, even if it conforms with right only to a small degree, is better than none, and the latter fate (anarchy) would result from premature reform. Political wisdom, therefore, will make it a duty, given the present state of things, to evaluate reform against the ideal of public right" (8: 373). This cannot be done without knowing the empirical conditions of a given society.

Political wisdom requires the guidance of morality, but it also needs experience of the given empirical situation and the sense of appropriateness that connects existing institutions to ideas of right. The "despotic moralist" lacks this wisdom because of a failure of prudence, a sense of appropriateness, in applying morality to actual circumstances. Politics is thus not the art of the despotic or naive moralist untempered 
by prudence. It is also not mere prudence, since the failures of the moralist can be better corrected by experience than by the abandonment or denial of morality. It is not, therefore, prudence alone. Prudence acting on its own might lead to some consideration of the public good, even if it is only the happiness of a rational selfinterested agent, but it also leaves society open to the devious practices by which the political moralist goes wrong (8: 373).

Prudence, as the art of the political, cannot properly reject ideas of right. To do this is the practice of the political moralist who Kant criticized for creating injustice and servitude through "enlightened" self-interest and concern for power (8: 373). This text thus indicates two notions of prudence. The first is the self-interest of the politician who undermines all concepts of right in his quest to maximize power. The second is the sense of appropriateness that guides the moral politician in considering political realities in accordance with ideas of right. Prudence in this sense cannot function without a sense of the practices and institutions, and of what is possible in a given set of circumstances.

Kant established in this essay a view of politics which connected the demands of morality with a pragmatic concern for the historical context. Prudence, insofar as it is guided by morality in working with it (8: 385), operates essentially as a context-sensitive application of general norms in the pragmatic application of the ideas of right (8: 380). According to Kant, "prudence cautions us not to employ power in direct pursuit of it [the end of right], but rather to approach it indirectly through those conditions presented by favorable circumstances" (8: 378). Since the application of right to reality is an indirect art that must consider circumstances, it is no longer the kind of application that Kant wrote of in the Metaphysics of Morals as following directly from the principle of right.

This coordination of the moral law and its context-sensitive application constitutes a political wisdom that aims at a moral end. This wisdom combines the art of political prudence with the law of morality. But this coordination is itself not an art because it operates according to morality: "True politics cannot progress without paying homage to morality; and although politics by itself is a difficult art, its union with morality is not art at all, for this union cuts through the [Gordian] knot that politics cannot solve when politics and morality come into conflict" (8: 380). Although the coordination is itself not art, because it is demanded by morality, the contribution of politics remains art in adjusting the demands of justice, the ideal republic, to historical circumstances. This "adjustment" can only be justified by the circumstances themselves, and Kant repeatedly asks his readers to be patient with those moral politicians who are pragmatically working toward a just system of government.

\section{CONCLUDING REFLECTIONS}

A further evaluation of the possibility of phronesis in Kant's practical philosophy requires a reconsideration of Kant's concept of moral judgment. To consider what the concept of phronesis would mean in the context of Kantian ethics, one would need to articulate his account of moral judgment and not only what Kant wrote 
about prudence. ${ }^{28}$ One would need to consider the relation of prudence and providence in history, and the notion of hope in happiness both in history and in the supreme good. This paper had the more modest aim of showing the underappreciated importance of prudence in Kant's larger practical thought. The legitimate role of prudence, understood as a sense of appropriateness, indicates that the charge of a lack of a context-sensitive application is an oversimplification of Kant's practical philosophy.

Prudential critics find Kant's practical philosophy lacking in prudence as a sense of appropriateness and in the practical wisdom that envisions the good life. Kant is accused of "a thoroughgoing renunciation of ancient practical philosophy" (Beiner, 1983, 63-64). To the contrary, this paper has argued that Kant retained significant elements of ancient moral thought. Kant is in partial agreement with the Aristotelian tradition on this issue, since Aristotle and Thomas Aquinas also argued for the role of reason and reflection in ethics. They never argued for the thesis that prudence is without principle or that something is good merely because it is a tradition, habit, or custom. This claim reflects a contemporary approach that rejects the possibility of practical reason, whether Aristotelian or Kantian.

Kant's moral theory, despite the centrality of the moral law and of common moral understanding as opposed to any type of moral expertise, leaves room for appropriate judgment and practical wisdom. ${ }^{29}$ The relative priority of morality over happiness does not signify the exclusion of happiness suggested by some critics. ${ }^{30}$ Kant even gave happiness a complementary role to morality in the doctrine of the supreme good. Happiness is not the incentive for acting morally; rather, it is described as a result hoped for by prudence. According to Kant, happiness is the primary condition and motive of prudence, and "All hoping is directed to happiness" (A 805/B 833). Kant insisted in a number of other works on the power of hope both in history and religion. If hope remains crucial to Kant's practical philosophy, then happiness-although not a moral foundation, justification, or motive-must remain in some sense a consequence of the moral law in the union of morality and happiness that constitutes the supreme good. If happiness and hope are irrelevant, then Kant would not have privileged the supreme good as happiness in accordance with moral worth.

\footnotetext{
${ }^{28}$ Judgment is the mediating link between theory and practice (8: 275), and in effect prudence is another type of practical judgment, one that as a sense of appropriate application negotiates between the demands of morality and those of context. The difficulty of prudential judgment is that it is much more likely to be in error, since it is empirically contingent (8: 299).

${ }^{29}$ Kant often plays common moral understanding and moral expertise or wisdom off each other, thereby leaving room for the imperfect embodiment of wisdom in the sage.

${ }^{30}$ Kant rejected the renunciation of happiness and pointed out that the promotion of happiness is an indirect duty insofar as it promotes one's ability to act morally (5: 93; see also 5: 63).
} 
